\title{
GROSS MORPHOMETRICAL STUDY ON BURSA OF FABRICIUS IN DEVELOPING BRONZE TURKEY (MELEAGRIS GALOPAVO)
}

\author{
G. Penchev* \\ Department of Veterinary Anatomy, Histology and Embryology, Faculty of Veterinary Medicine. \\ Trakia University, Stara Zagora, Bulgaria
}

\begin{abstract}
The aim of the study was an evaluation of the age related development of bronze turkey's bursa of Fabricius. The obtained data gave information about the standard actual values of the metric parameters in the investigated organ. The bursa of sixty healthy clinically bronze turkeys (30 males and 30 females) was studied metrically by ruler, graph paper and automatic balance. The birds were distributed in 10 age related groups at the 1, 7, 14, 28, 35, 49, 56, 90, 120 and 240 days. Each group consisted of 6 turkeys. The absolute and relative weight, length, perimeter and diameter of the organ were determined. During the period the absolute weight of the bronze turkeys' bursa increased by 76.5 times, the absolute length - 3.5 times. The relative weight of the organ was with the highest values at the 14 days of age. The relative length reached peak values at the 1 day. The relative perimeter was highest at 7 days. The obtained results gave a motivation to make the conclusion that the development of the bronze turkey bursa of Fabricius weight and length were highest from hatching to the sexual maturity.
\end{abstract}

Key words: bronze turkey, bursa of Fabricius, weight, length, diameter, perimeter

\section{INTRODUCTION}

Bursa of Fabricius is a lymphoepithelial organ that is found only in birds. The primary lymphoid organs in birds include the thymus and the bursa of Fabricius, which are the places where lymphocytes develop and T-cell and B-cell receptor genes rearrange. Then the lymphocytes migrate to secondary lymphoid organs: spleen, coecal tonsils and the lymph nodes (1). That is why these organs play a primordial role in the poultry immunity. The major components of the body defense mechanism are the innate and acquired or adaptive immunity. Innate immunity includes physical barriers like skin and mucous membrane, complement and cells like macrophages granulocytes, while acquired immunity is mediated by immunocompetent cells, humoral response B-cells, cell mediated response T-cells (2). The cloacal bursa is an oval sacculated organ dorsal to the cloaca and communicating with it by a short duct.

\footnotetext{
*Correspondence to: Georgi Penchev, Department of Veterinary Anatomy, Histology and Embryology, Faculty of Veterinary Medicine. Trakia University, 6000 Stara Zagora, Bulgaria, georgi_pnchv@yahoo.com
}

Standard bronze turkeys in Republic Bulgaria are well adapted and resistant to environmental influences, hence very appropriate for outdoor rearing until late autumn. These traits make them suitable for breeding in pheasant farms of South Bulgaria in order to be used for hunting in game reserves (3). It has been found that the bursa is well developed in sexually immature birds but at the onset of sexual maturity undergoes involution. Some authors describe that in Pekin ducks there was a total loss of lymphoid follicles which left the bursa a fibrous sack (4), while in guinea fowl even at age of 224 days, the bursa had not completely involuted and was still functionally active (5).

The age dependent changes in avian lymphoid organs have been poorly investigated. Most research has been focused on the structure and function in mammalian primary lymphoid organs. The information about the age dependent changes in avian cloacal bursa is scarce, fragmentary and heterogeneous. Most research on bursal development in birds however has been focused on chicken (Gallus domesticus). Hence this study is aimed to investigate the age-related morphometric 
changes, associated with the growth of the bursa of Fabricius from day one post hatch to day 240 of age in bronze turkey (Meleagris meleagris gallopavo).

\section{MATERIAL AND METHODS}

Biological material was obtained from 60 clinically healthy common bronze turkey poults and turkey (Meleagris meleagris gallopavo) purchased from the pheasant farm, Trankovo, Stara Zagora region. The birds were at $1,7,14,21,28,35,49,56,90,120$ and 240 days. Each of the 10 groups consisted of 6 birds ( 3 males and 3 females). The selected age groups include the period from 1 day of age to the sexual maturity and economical realization (240 days of age).

The individual live body weights of the birds were determined before the removal of avian cloacal bursa by means of automatic balance ADAM AAA100L (Czech Republic). All procedures were performed as per requirements of the Trakia University Animal Ethics Committee. After inhalation anaesthesia followed by decapitation, bursa of Fabricii was obtained from each bird by dissection. Each of the cloacal bursae was removed, freed from adhering tissue and weighed individually on automated balance Sartorius AY303 (USA). The absolute metric parameters (length, perimeter, diameter) of each bursa of Fabricius were determined by means of a ruler and graphing paper. Relative organ parameters were calculated as organ parameters as percentages of body weight. All the measurements recorded were statistically analyzed by estimating the Arithmetic mean and standard deviation (S.D.) and presented in tables.

\section{RESULTS}

During the period from day old to 240 day of age all investigated absolute parameters increased constantly (Table 1).

Table 1. Absolute parameters of bursa of Fabricius in common bronze turkey.

\begin{tabular}{c|c|c|c|c|c|}
\hline \multirow{2}{*}{$\begin{array}{c}\text { age } \\
\text { (days) }\end{array}$} & $\begin{array}{c}\text { weight (g) } \\
\mathrm{x} \pm \mathrm{SD}\end{array}$ & $\begin{array}{c}\text { length (mm) } \\
\mathrm{x} \pm \mathrm{SD}\end{array}$ & $\begin{array}{c}\text { perimeter }(\mathrm{mm}) \\
\mathrm{x} \pm \mathrm{SD}\end{array}$ & $\begin{array}{c}\text { diameter (mm) } \\
\mathrm{x} \pm \mathrm{SD}\end{array}$ & $\begin{array}{c}\text { body weight }(\mathrm{g}) \\
\mathrm{x} \pm \mathrm{SD}\end{array}$ \\
\hline 1 & $0.06 \pm 0.01$ & $8.83 \pm 0.75$ & $11.50 \pm 0.83$ & $3.37 \pm 0.51$ & $50.76 \pm 3.14$ \\
\hline 7 & $0.15 \pm 0.02$ & $11.83 \pm 1.60$ & $17.83 \pm 0.98$ & $5.33 \pm 0.51$ & $77.43 \pm 1.53$ \\
\hline 14 & $0.34 \pm 0.02$ & $15.66 \pm 0.81$ & $21.02 \pm 0.89$ & $7.07 \pm 0.63$ & $125.57 \pm 2.56$ \\
\hline 28 & $0.85 \pm 0.01$ & $18.16 \pm 0.75$ & $29.33 \pm 1.63$ & $11.34 \pm 0.51$ & $347.37 \pm 13.86$ \\
\hline 35 & $0.96 \pm 0.02$ & $23.02 \pm 1.09$ & $32.07 \pm 0.63$ & $12.33 \pm 0.56$ & $433.83 \pm 12.02$ \\
\hline 49 & $1.15 \pm 0.02$ & $23.50 \pm 0.54$ & $32.38 \pm 0.51$ & $14.54 \pm 0.83$ & $489.94 \pm 11.89$ \\
\hline 56 & $2.31 \pm 0.24$ & $24.16 \pm 0.98$ & $32.51 \pm 1.04$ & $15.16 \pm 0.75$ & $1102.52 \pm 97.41$ \\
\hline 90 & $3.74 \pm 0.07$ & $25.66 \pm 0.51$ & $33.16 \pm 1.169$ & $17.39 \pm 0.81$ & $2493.74 \pm 51.03$ \\
\hline 120 & $3.98 \pm 0.06$ & $27.50 \pm 0.54$ & $34.31 \pm 0.51$ & $19.52 \pm 0.54$ & $3089.16 \pm 86.39$ \\
\hline 240 & $4.65 \pm 0.46$ & $30.58 \pm 0.54$ & $35.52 \pm 0.547$ & $20.19 \pm 0.75$ & $4964.5 \pm 144.37$ \\
\hline
\end{tabular}

The mean weight of the bursa of Fabricius increased 76.5 times-from $0.06 \mathrm{~g}$. at day 1 after hatching to $4.65 \mathrm{~g}$. at 240 days of age and highest increment was observed in the periods $14-28$ days and 56-90 days. The mean length increased 3.5 times - from $8.83 \mathrm{~mm}$ to 30.58 $\mathrm{mm}$. The perimeter increased 3 times - from $11.50 \mathrm{~mm}$ to $35.52 \mathrm{~mm}$. Here the highest increment was found between 14 and 28 days. The mean diameter increased 6 times - from $3.37 \mathrm{~mm}$ to $20.19 \mathrm{~mm}$.

The relative parameters changed in different way during the investigated period (Table 2).
The relative weight of bursa of Fabricius increased gradually and the maximum was attained at 14 days of age. Thereafter the bursal weight decreased lightly up to 240 days of age in both sexes. The relative length had peak value at day old and after that decreased gradually to the end of the examined period. The maximum relative perimeter was reached to the age of 7 days $(23.08 \mathrm{~mm})$ and lightly decreased to 0.72 $\mathrm{mm}$ at 240 days of age. The relative diameter of bursa attained maximum average value at 7 days of age and after that gradually decreased to 0.41 $\mathrm{mm}$ up to 240 days of age. 
Table 2. Relative parameters of bursa of Fabricius of bronze turkey.

\begin{tabular}{c|c|c|c|c|c|}
\hline \multirow{2}{*}{$\begin{array}{c}\text { age } \\
\text { (days) }\end{array}$} & $\begin{array}{c}\text { weight (g) } \\
\mathrm{x} \pm \mathrm{SD}\end{array}$ & $\begin{array}{c}\text { length (mm) } \\
\mathrm{x} \pm \mathrm{SD}\end{array}$ & $\begin{array}{c}\text { perimeter }(\mathrm{mm}) \\
\mathrm{x} \pm \mathrm{SD}\end{array}$ & $\begin{array}{c}\text { diameter }(\mathrm{mm}) \\
\mathrm{x} \pm \mathrm{SD}\end{array}$ & $\begin{array}{c}\text { body weight }(\mathrm{g}) \\
\mathrm{x} \pm \mathrm{SD}\end{array}$ \\
\hline 1 & $0.12 \pm 0.01$ & $17.83 \pm 0.75$ & $23.08 \pm 0.83$ & $6.74 \pm 0.51$ & $50.76 \pm 3.14$ \\
\hline 7 & $0.19 \pm 0.01$ & $15.83 \pm 0.60$ & $23.13 \pm 0.88$ & $6.92 \pm 0.41$ & $77.43 \pm 1.53$ \\
\hline 14 & $0.27 \pm 0.03$ & $12.66 \pm 0.71$ & $16.82 \pm 0.79$ & $5.65 \pm 0.23$ & $125.57 \pm 2.56$ \\
\hline 28 & $0.24 \pm 0.01$ & $5.26 \pm 0.75$ & $8.43 \pm 1.23$ & $3.24 \pm 0.48$ & $347.37 \pm 13.86$ \\
\hline 35 & $0.23 \pm 0.02$ & $5.30 \pm 0.09$ & $7.40 \pm 0.63$ & $2.84 \pm 0.46$ & $433.83 \pm 12.02$ \\
\hline 49 & $0.22 \pm 0.02$ & $4.80 \pm 0.59$ & $6.62 \pm 0.51$ & $2.94 \pm 0.83$ & $489.94 \pm 11.89$ \\
\hline 56 & $0.21 \pm 0.04$ & $2.16 \pm 0.78$ & $1.37 \pm 0.54$ & $15.16 \pm 0.75$ & $1102.52 \pm 97.41$ \\
\hline 90 & $0.15 \pm 0.04$ & $1.02 \pm 0.51$ & $1.33 \pm 0.16$ & $1.39 \pm 0.72$ & $2493.74 \pm 51.03$ \\
\hline 120 & $0.12 \pm 0.02$ & $0.89 \pm 0.50$ & $1.11 \pm 0.31$ & $0.69 \pm 0.04$ & $3089.16 \pm 86.39$ \\
\hline 240 & $0.09 \pm 0.01$ & $0.61 \pm 0.57$ & $0.72 \pm 0.04$ & $0.41 \pm 0.05$ & $4964.5 \pm 144.37$ \\
\hline
\end{tabular}

\section{DISCUSSION}

In the present study the postnatal growth of the bursa of Fabricius of the bronze turkey was clarified with special attention given to absolute and relative weight, length, perimeter and diameter of the bursa. According to these values we can evaluate the functional activity of the bursa of Fabricius.

The development of the bursa of Fabricius after hatching was studied by many investigators. In white Pekin ducks (4) described that the mean maximum weight of bursa occurred at 9 weeks of age, while (6) reported that mean weight, length and diameter of bursa attained maximum values at 58 days of age. Some authors showed that in broiler chicken the bursal weight increased constantly until 10 weeks of age $(7,8)$. In Japanese quails , as reported by (9) the bursa attained its maximum weight at 7 weeks in the males and at 6 weeks in the females, while (10) showed that maximum weight was reached at 5 weeks of age in both sexes. Ward and Middleton, (11) described that in wild mallards the bursal weight attained its maximum at 8 weeks in males and 6 weeks in females. Tamilselvan et. at. (12) informed that in guinea fowl the weight and diameter of the bursa reached maximum values at the age of 4 months, while (5), reported that in guinea fowl even at the age of 224 days the bursa had not completely involuted and was still functionally active. Our results were closed to these studies because the weight, length and diameter of bursa in bronze turkey increased until 240 days if age. Also in turkey (13) showed that bursa reached maximum weight and diameter at the age of 6 months. The difference may be attributed to difference in breeding conditions. Studying the development of the bursa of Fabricius in the Partridge and Pheasant (14) makes the conclusion that the age appeared to be a more important factor than bodyweight with regards to bursal regression. The physiological involution was in close relationship to sexual maturity.

The results concerning the weight of the bursa of Fabricius in normal condition can be used in the diagnosis of viral diseases, where the weight changes. Some authors described decreasing the weight of bursa under the influence of Gumbaro disease (15 and 16), or Marek disease (17)

The development of the bursa of Fabricius reacted to the influence of different factors. According to (18) birds under heat stress had a smaller bursa as compared to healthy birds. For reducing of the weight of the bursa in broiler chicken reported (19) in ochratoxicosis; (20) in afhatoxicosis and (21) under chemotherapy Since bursa of Fabricius has a role in the humoral immune response of the birds, an increase of mean weight of the bursa and higher percentage of increment in bursal weight during early phase in postnatal life indicate fast development of immune system in yang birds for effectively countering the infectious agents during early post hatch periods. (22) 


\section{CONCLUSION}

The obtained results gave a motivation to make the conclusion that the development of the bursa of Fabricius in bronze turkey is age dependent. The absolute and relative parameters of the bursa can be used to assess the health status of the birds.

\section{REFERENCES}

1. Eurel, J. and Frappier B., Delmann`s Textbook of Veterinary Histology, 6 edition, Blackwell Publishing, Ames, Iova, USA, 2006.

2. Ciriaco, E., Pinera, P., Dias-Esnal, B., Laura,L., Age-related changes in the avian primary lymphoid organs (thymus and bursa of Fabricius). Microscopy Research \& Technics, 62, 482-487, 2003.

3. Dimitrov, D., Penchev, G., Yovchev, D., Stamatova-Yovcheva, K., Age-related light microscopy histometric investigation on bursa of Fabricius in the common bronze turkey (Meleagris meleagris gallopavo). Bulgarian Journal of Veterinary Medicine, 20, Suppl. 1, 71-75, 2017.

4. Hashimoto, Y. and Sugimura, M., Histological and quantitative studies on the postnatal growth of the thymus and the bursa of Fabricius of White Pekin ducks. Jap. J. Vet. Res., 24, 65-76, 1976.

5. Onyeanusi, B., Ezeokoli, C., Onyeanusi, J., Emma, A., The anatomy of the cloacal bursa in the helmeted Guinea fowl. Anat. Histol. Embryol., 22, 212-221, 1993.

6. Indu, V., Chungath, J., Harshan, K., Ashok, N., A morphological study on the postnatal development of the bursa of Fabricius in White Pekin duck. Indian Journal of Poultry Science, 35, 2, 124-127, 2000.

7. Yamada, J., The weight and the histological changes with age of the bursa of Fabricius in chickens. Japan. Journal of Veter. Res., 14, (3-4) 136, 1966.

8. Nabil Alloui, M, Sellaoui, Djaaba, S., Morphometrical and anatomopathological survey of the bursa of Fabricius in broiler chickens. ISAH - Warsaw, Poland, 2, 5254.2005.

9. Yamada, J., Tanaka, H., Iwasa, K., Yamashita, T., Misu, M., Res. Bull. Obihirio Univ., 7, 1, 1971.

10.Lavanya, C., Balasundaram, K., Jayachitra, S., Madheswaran, R., Gross morphological study on the bursa of Fabricius in Japanese quail (Coturnix coturrnix Japonica). Journal of Entomology and Zoology Studies, 7,3, 6769, 2019.

11.Ward, J., Middleton, A., Weight and histological studies of growth and regression in the bursa of Fabricius in the mallard, Anas platyrhynchos. Canadian Journal of Zoology, 49,1, 11-14, 1971.

12. Tamilselvan, S., Balasundaram, K., Jayachitra, S., Gross anatomy of bursa of Fabricius in Guinea Fowl (Numida meleagris). Indian Veterinary Journal, 1, 1416, 2017.

13. Jayachitra, S., Balasundaram, K., Kumaravel, A., Ramayya, P., ., Gross anatomy of bursa of Fabricius of turkey (Meleagris gallopavo). Indian Journal of Veterinary Anatomy, 21, 1, 33-36, 2009.

14. Mercer-Oltjen, S., Woodard, A., Development of the bursa of Fabricius in in the Partridge and Pheasant. Poultry Science 66, 3, 418-421, 1987.

15. Khenenou, T., Bougherara, M., Melizi, M., Lamraoui, R., Histomorphological study of the bursa of Fabricius of broiler chickens during Gumboro disease in Algeria area. Global Veterinaria, 18, 2, 132-136, 2017.

16. van der Berg, T., Eterradossi, N., Toquin, D., Meulermans, G., Infectious bursal disease (Gumbaro disease). Revue Scientifique et Technique, 19, 2, 509-543, 2000.

17. Semerdzhiev, V., Bochukov, A., Comparative investigation of Fabrician bursa weight in chickens not infected and infected with Marek`s disease nd the effect of low dose gamma-irradiation on it. Genetics and Breeding, 24, 6, 447-452, 1991.

18. Khenenou, T., Melizi, M., Benzaoui, H., Ibrir, M., Histological study of thr bursa of Fabricius of broiler chickens during heat stress. Intern. Journ., of Poultry Science, 12, 6, 377-378, 2013.

19.Elaroussi, M., Mohamed, F., Elgendy, M., El Barkouky, E., Abdou, A., Hatab, M., Ochratoxicosis in broiler chickens: Functional and histological changes in target organs. Intern. Journ., of Poultry Science, 7, 5, 414422, 2008.

20. Valchev, I., Hristov, Ts., Lazarov, L., Kanakov, D., Binev, R., Nikolov, Y., Investigations on production traits in broiler chickens with experimental aphlatoxicosis. Bulgarian Journal of Veterinary Medicine, 16, 4, 271-281, 2013

21.Karim, M., Khan, M., Haque, Z., Morphometrical analysis of major lymphoid organs of chemotherapy treated chickens, Bangl. Journ., of Veter, Medic., 3. 2, 1-4, 2005

22. Singh, S., Singh, I., Singh, G., Saxena, S., Garg, V., Gross morphometrical observation on bursa of Fabricius in developing guinea fowls (keets). J. Immunol. Immunopathol., 8, 1, 67-70, 2006. 
PENCHEV G. 